ISSN (Print) : :1412-7601

ISSN (Online) : 2654-8712

Volume 7, No. 1 Maret 2021

EKONOBIS

http://www.ekonobis.unram.ac.id

\title{
MODEL PENGEMBANGAN LEMBAGA KEUANGAN MIKRO SYARIAH DALAM MENGURAI KEMISKINAN DI KOTA MATARAM
}

\author{
Irwan Suriadi, Hailuddin, Siti Sriningsih.
}

Universitas Mataram

\begin{tabular}{l}
\hline ARTICLE IN FO \\
\hline Keywords: \\
Sharia Microfinance \\
Institution, SWOT \\
Analysis, Mataram City
\end{tabular}

Kata Kunci:

Lembaga Keuangan Mikro Syariah, Analisis SWOT, Kota Mataram

\begin{abstract}
This research aims to create a poverty reduction formula with the development policy of Islamic microfinance institutions in Mataram city. The research approach used is a qualitative approach with the Focus Group Discussion (FGD) method. In designing policies for the development of Islamic microfinance institutions to reduce poverty in the City of Mataram, a SWOT analysis is used (Strength, Weakness, Opportunity, Threath). The results showed that the supporting factors can be seen from the strengths and opportunities possessed by Islamic Microfinance Institutions in Mataram City, namely Baitul Maal Wattamwil (BMT) in Mataram City must have a strategic location and community empowerment By Islamic Microfinance Institutions, inhibiting factors can be seen From the weaknesses and threats possessed by Islamic Microfinance Institutions in Mataram City, namely the lack of socialization and Islamic Banks working on the micro market, the policy strategy of Islamic Micro Finance Institutions in facing threats, namely Islamic Microfinance Institutions in Mataram City must continue to develop themselves creatively, innovative and always have improvements in services to customers of Islamic Microfinance Institutions.

ABSTRAK: Penelitian ini bertujuan untuk membuat suatu rumusan penanggulangan kemiskinan dengan kebijakan pengembangan lembaga keuangan mikro syariah di Kota Mataram. Pendekatan penelitian yang digunakan adalah pendekatan kualitatif dengan metode Fokus Group Discussion (FGD). Dalam merancang kebijakan pengembangan lembaga keuangan mikro syariah untuk mengurangi kemiskinan di Kota Mataram, maka digunakan analisis SWOT (Strength, Weakness, Opportunity, Threath). Hasil Penelitian menunjukkan bahwa Faktor pendukung dapat dilihat dari kekuatan dan peluang yang dimiliki oleh Lembaga Keuangan Mikro Syariah di Kota Mataram yaitu Baitul Maal Wattamwil (BMT) di Kota mataram harus memiliki lokasi yang strategis dan pemberdayaan masyarakat Oleh Lembaga Keuangan Mikro Syariah, Faktor Penghambat dapat dilihat dari kelemahan dan ancaman yang dimiliki oleh Lembaga Keuangan Mikro Syariah di Kota Mataram yaitu kurangnya sosialisasi dan Bank syariah yg menggarap pasar mikro, Strategi kebijakan Lembaga Keuangan Mikro Syariah dalam menghadapi ancaman yaitu Lembaga Keuangan Mikro Syariah di Kota Mataram harus terus menerus mengembangkan diri secara kreatif, inovatif dan selalu memiliki perbaikan dalam pelayanan kepada nasabah Lembaga Keuangan Mikro Syariah.
\end{abstract}

Corresponding Author:

Alamat : Program Studi Ekonomi Pembangunan, Fakultas Ekonomi dan Bisnis, Universitas Mataram, Jln. Majapahit No. 62 Mataram.

e-mail:irwansuryadi@unram.ac.id 


\section{PENDAHULUAN}

\section{Latar Belakang}

Di dalam suatu perekonomian kemiskinan merupakan masalah yang sangat mendasar untuk di pecahkan dengan berbagai cara dan startegi. Salah satunya dengan pemberdayaan masyarakat kecil melalui pemberian akses modal untuk digunakan dalam kegiatan produktif (berdagang), terutama masyarakat yang berada pada sektor informal yang selama ini terpinggirkan. Sektor informal merupakan salah satu penyangga perekonomian nasional yang memiliki peranan yang sangat besar di dalam mengurangi kemiskinan. Besarnya peranan sektor informal di dalam aktivitas ekonomi diseluruh negara berkembang dan keterpurukan ekonomi dinegara berkembang desebabkan oleh ketiadaan modal (Hernande de Soto,2001). Di mana asset di negara berkembang tidak mampu menjadi modal kerja karena tersandung masalah kepemilikan (property right) dan belum efektifnya lembaga keuangan mikro yang langsung melayani dan menjangkau sektor usaha mikro, kecil dan sektor informal yang secara memadai mampu memberikan alternatif pelayanan baik simpan-pinjam maupun pembiayaan yg sesuai dengan kondisi sosial kultural serta sekarbele, Mataram, ampenan, selaparang, cakranegara, sandubaya .Kota Mataram memiliki total jumlah penduduk sebanyak 468.509 jiwa (BPS kota mataram dalam Angka,2018). Tingkat kemiskinan di Kota Mataram dalam kurun waktu 7 tahun terakhir menunjukkan penurunan jumlah penduduk miskin dari 53.736 Jiwa $(13,18$ \%) pada tahun 2011 menjadi 820.820Jiwa $(17,24 \%)$ pada tahun 2014, akan tetapi jika dilihat dari persentase, penduduk miskin di Kota Mataram tergolong masih tinggi berada di atas $15 \%$.

Tabel 1.Jumlah dan Persentase Penduduk Miskin di Kota Mataram (2011-2017)

\begin{tabular}{|r|r|r|}
\hline Tahun & $\begin{array}{c}\text { Jumlah } \\
\text { penduduk } \\
\text { miskin (Jiwa) }\end{array}$ & $\begin{array}{c}\text { Persentase } \\
\text { penduduk miskin } \\
\text { (\%) }\end{array}$ \\
\hline 2011 & 53736 & 13,18 \\
\hline 2012 & 49633 & 11,87 \\
\hline 2013 & 46674 & 10,75 \\
\hline 2014 & 46673 & 10,53 \\
\hline 2015 & 46760 & 10,45 \\
\hline 2016 & 44810 & 9,80 \\
\hline 2017 & 44529 & 9,55 \\
\hline
\end{tabular}

Sumber: BPS Mataram dalam Angka 2018

Masih tingginya tingkat kemiskinan di Kota Mataram ini diakibatkan oleh kurangnya perhatian pemerintah dalam mengembangkan dan mensinergikan lembaga keuangan mikro yang dapat menjangkau masyarakat di tingkat paling bawah (masyarakat ekonomi lemah) 
terutama pada akses permodalan untuk menjalankan usaha yang sedang atau akan dirintis untuk mendapatkan penghasilan.

Daerah Kota Mataram memiliki jumlah penduduk dengan mayoritas muslim yang bekerja diberbagai sector, terutama sector informal seperti bekerja disektor pertanian, perdagangan dan jasa. Permasalahan yang sering muncul dari para pekerja informal terutama pedagang adalah akses permodalan dari perbankan yang sangat kurang, belum lagi persyaratan perbankan yang terkadang memberatkan para debitur kecil seperti jaminan, platfon pembiayaan yang rumit sampai dengan proses administrasi yang sangat memberatkan debitur kecil tersebut.

Peranan sector informal di daerah Kota Mataram seperti para pedagang kecil, pedagang kaki lima dan para penjual keliling sangat besar, oleh karena itu dibutuhkan akses permodalan yang cukup kuat agar keberlangsungan usaha mereka akan tercapai. Pemerintah dapat memberikan kesempatan kepada lembaga keuangan yang akses permodalannya kuat seperti lembaga keuangan mikro syariah. Lembaga keuangan mikro ini memang masih kurang dikenal oleh masyarakat kota mataram karena lembaga keuangan mikro ini belum banyak berdiri di daerah Kota
Mataram ini. Lembaga ini dapat memberikan pinjaman kepada debitur dengan pinjaman yang sangat rendah mulai dari Rp 50.000 - Rp 30.000.000, bank besar atau lembaga keuangan besar kadangkala tidak mau memberikan pinjaman yang rendah seperti yang dilakukan lembaga keuangan mikro syariahkarena keuntungan yang diharapkan dari pinjaman tersebut kecil.

Dengan adanya kemudahan akses permodalan yang diberikan lembaga keuangan mikro syariah dapat menjadi solusi untuk mengurangi kemiskinan di Kota Matarammelalui pemberdayaan masyarakat terutama para pedagang yang bergerak di sector informal dengan pemberian kredit lunak yang diharapkan dapat membantu para pedagang dalam rangka keberlangsungan usaha mereka.

\section{Rumusan Masalah}

Bagaimana model pengembangan Lembaga Keuangan Mikro Syariahdalam mengurai kemiskinan di Kota Mataramserta rumusan kebijakan yang harus dibuat oleh pemerintah daerah dalam memberikan permodalan bagi masyarakat kota mataram melalui lembaga keuangan mikro syariah, terutama bagi masyarakat miskin didaerah Kota Mataram.

\section{Tujuan dan Manfaat Penelitian}




\section{Tujuan Penelitian}

Berdasarkan latar belakang dan rumusan masalah diatas, maka tujuan dari penelitian ini adalah membuat formulasi kebijakan atau cetak biru/blue print pengembangan lembaga keuangan mikro syariah dalam rangka penanganan kemiskinan di daerah Kota Mataram.

\section{Manfaat Penelitian}

Sebagai masukan bagi pemerintah daerah, Otoritas Jasa Keuangan (OJK), Bank Indonesia (BI) dalam mengembangkan lembaga keuangan mikro syariah untuk mengatasi atau mengurangi kemiskinan di Kota Mataram.

\section{KAJIAN PUSTAKA}

\section{Penelitian Terdahulu}

Penelitian yang dilakukan oleh Hendayana dan Bustaman (2007)mengkaji tentang fenomena lembaga keuangan mikro dalam persfektif pembangunan ekonomi pedesaan dengan menggunakan metode group interview dan individual indept interview, hasilnya adalah pengembangan lembaga keuangan mikro sangat tergantung dari kemampuan lembaga keuangan mikro dalam memaksimalkan peluang dan kekuatan serta meminimalisir kelemahan dan ancaman yang muncul, lembaga keuangan mikro dijadikan salah satu instrumen kebijakan pemerintah dalam upaya meningkatkan produktivitas pertanian menuju peningkatan pendapatan dan kesejahteraan petani yang sesuai dengan karakteristik kebutuhan permodalan petani, dan untuk dapat mengoptimalkan lembaga keuangan mikro sebagai instrumen kebijakan pemerintah yang efektif dan efisien, maka diperlukan pendekatan partisipatif dan penguatan sumber daya manusia lembaga keuangan mikro.

Wiloejo Wirjo Wiyono (2005) meneliti tentang pemberdayaan lembaga keuangan mikro sebagai salah satu pilar sistem keuangan nasional : upaya konkrit memutus mata rantai kemiskinan, Hasil dari penelitiannya adalah salah satu upaya yang dilakukan dalam mengentaskan kemiskinan adalah dengan memperluas akses UMKM dalam mendapatkan fasilitas permodalan terutama dari lembaga keuangan mikro, lembaga keuangan mikro ternyata dapat memberikan berbagai jenis pembiayaan yang dapat dijadikan alternatif dalam pembiayaan yang cukup potensial, dan upaya yang dapat dilakukan dalam mengembangkan lembaga keuangan mikro adalah dengan membuat payung hukum dalam bentuk undangundang lembaga keuangan mikro.

Nurkholis (2009) meneliti tentang kontribusi lembaga keuangan mikro di 
dalam meningkatkan kesejahteraan di indonesia dengan menggunakan metode kualitatif dalam analisisnya, hasil penelitiaanya adalah lembaga keuangan islam seperti Lembaga keuangan mikro syariahmemiliki peran yang sangat penting dalam kegiatan ekonomi dalam meningkatkan pendapatan masyarakat, mengurangi kemiskinan dan meningkatkan kesejahteraan sosial seperti yang dilakukan oleh Lembaga Keuangan Mikro Syariah Dana syariah sebagai salah satu lembaga yang memiliki peranan yang sangat penting dalam pembiayaan usaha mikro kecil.

Syeda Shehrbano Kazim dan Syed Eisar Haider (2012) meneliti tentang model lembaga keuangan mikro di Pakistan dengan menggunakan Waqf based model, hasil penelitiannya adalah model lembaga keuangan mikro yang digunakan dalam mengurangi kemiskinan bagi masyarakat miskin adalah pinjaman dalam bentuk Qardhasan, yaitu pemberian pinjaman sukarela dari hasil keuntungan lembaga keuangan dan pinjaman dalam bentuk takaful (tolong menolong).

Asyraf Wajdi Dusuki (2007) melakukan penelitian yang berkaitan dengan bank bagi orang miskin, model yang digunakan adalah special purpose vehicle (SPV) sebagai chaneling bagi orang miskin hasil penelitiannya adalah transaksi keuangan di dalam islam ditujukan untuk mengurangi kemiskinan, keadilan sosial dan untuk distribusi kekayaan yang adil dan merata. Lembaga keuangan islam perlu melakukan inovasi dimasa yang akan datang dalam peranannya sebagai lembaga intermediasi, meningkatkan kemampuan dan kapasitas sumberdaya manusia

Suriadi (2015) melakukan penelitian yang sama dengan lokasi yang lebih kecil yaitu hanya wilayah pulau Lombok saja dan variabel yang digunakan masih sedikit. Hasil penelitiannya menyatakan bahwa Terdapat beberapa perbedaan antara penelitian sebelumnya dengan penelitian yang akan dilakukan yaitu:

1. Lokasi penelitian yang akan dilakukan wilayahnya diperluas menjadi seluruh provinsi Kota Mataram (Kota Mataram)

2. Terdapat penambahan beberapa variabel dalam penelitian yang akan dilakukan

\section{Sistem Ekonomi Islam}

Sistem ekonomi islam merupakan sistem ekonomi yang berlandaskan pada prinsipprinsip yang terkandung di dalam Al-qur'an dan Al-hadis.

Nilai-nilai yang terkandung di dalam sistem ekonomi islam terdiri dari (Antonio,2001;30-17): 
1. Perekonomian masyarakat luas yang mengacu pada norma-norma islami terdapat banyak ayat di dalam AlQur'an yang menyerukan pada penggunaan kerangka kerja perekonomian islam seperti yang terkandung pada surat Al-Baqarah ayat 60 yang artinya "Makan dan minumlah dari rezeki (yang diberikan) Allah SWT dan janganlah berkeliaran di muka bumi ini dengan berbuat kerusakan".

Dari ayat diatas dapat dipahami bahwa islam mendorong penganutnya untuk menikmati karunia yang telah diberikan oleh Allah SWT, dimana karunia tersebut harus didayagunakan untuk meningkatkan pertumbuhan baik materi maupun nonmateri.

2. Keadilan dan persaudaraan menyeluruh. Islam bertujuan untuk membentuk masyarakat dengan tatanan sosial yang solid, di mana setiap individu diikat oleh persaudaraan dan kasih sayang bagai satu keluarga. Hal ini terlihat di dalam surat Al-Hujurat ayat 13 artinya "Hai Manusia, Sesungguhnya kami menciptakan kamu dari seorang lakilaki dan seorang perempuan serta menjadikan kamu berbangsa-bangsa dan bersuku-suku agar kamu saling mengenal. Sesungguhnya orang yang paling mulia diantara kamu disisi Allah SWT adalah orang yang paling bertaqwa. Sesungguhnya Allah SWT maha mengetahui lagi maha mengenal".

Islam selalu mengajarkan keadilan dan memberi peringatan kepada orang yang tidak berlaku adil seperti yang tercantum di dalam Hadis yang diriwayatkan oleh Imam Ahmad yang artinya "Wahai manusia, takutlah akan kezaliman (ketidakadilan) sebab sesungguhnya dia akan menjadi kegelapan pada hari pembalasan nanti."

3. Keadilan Distribusi Pendapatan. Adanya kesenjangan pendapatan dan kekayaan alam yang ada didalam masyarakat berlawanan dengan semangat serta komitmen islam terhadap persaudaraan dan keadilan sosial ekonomi. Kesenjangan tersebut harus diatasi dengan menggunakan cara-cara yang ditekankan islam dengan cara :

a. Menghapuskan monopoli, kecuali oleh pemerintah untuk bidangbidang tertentu.

b. Menjamin hak dan kesempatan semua pihak untuk aktif di dalam proses ekonomi 
c. Menjamin pemenuhan kebutuhan dasar hidup setiap anggota masyarakat

4. Kebebasan individu dalam konteks kesejahteraan sosial. Islam mengakui pandangan universal bahwa kebebasan individu dibatasioleh kebebasan individu orang lain, seperti prinsip-prinsip dibawah ini ;

a. Kepentingan masyarakat yang lebih luas harus didahulukan dari kepentingan individu

b. Melepas kesulitan harus diprioritaskan dibanding memberi manfaat

c. Kerugian yang lebih besar tidak dapat diterima untuk menghilangkan yang lebih kecil.

\section{Lembaga Keuangan di dalam Islam} Lembaga keuangan memang tidak disebutkan secara eksplisit di dalam AlQuran, tetapi jika yang dimaksud lembaga itu sesuatu yang memiliki unsur-unsur seperti struktur, manajemen, fungsi serta hak dan kewajiban, maka semua lembaga tersebut disebutkan secara jelas seperti kata Ummat (Kelompok masyarakat), muluk (pemerintah), balad (negeri), suq (pasar)yang mengindikasikan fungsi dan perannya sama dengan lembaga yang ada saat ini (Muhammad,2002;21).
Sejarah lembaga keuangan dalam sejarah Islam

\section{Lembaga keuangan di zaman Rasulullah}

Lembaga keuangan yang didirikan pertamakali adalah baitul mal (lembaga penyimpanan) dengan melakukan operasional penerimaan pendapatan dan pembelanjaan yang transparan yang bertujuan untuk mencapai welfare oriented.

Lembaga lain yang juga didirikan oleh Rasulullah adalah Wilayatul Hisbah yang berfungsi sebagai pengawasan atau kontrol oleh negara yang dipegang langsung oleh rasulullah. Selain itu lembaga ini juga menjadi pilar infrastruktur yang menjadi bingkai bagi aktivitas ekonomi dan muamalat.

\section{Lembaga keuangan di zaman Khulafa} Rasyidin

Lembaga keuangan di zaman Khulafa Rasyidin meneruskan lembaga keuangan yang dibangun di jaman rasulullah, di mana baitul mal semakin mapan bentuknya. Pada masa Umar Bin Khatab memperluas basis zakat dan sumber pendapatan lain serta membuat kebijakan dengan memberlakukan kuota kepada para pedagang yang datang dari Persia dan Romawi, karena kedua negara tersebut memberlakukan hal yang sama kepada para pedagang di Madinah. Kebijakan 
Umar bin khatab diteruskan oleh Usman bin Affan dan Ali bin Abi Thalib dengan memaksimalkan pendapatan dan penerimaan dari baitul mal yang berfungsi sebagai kebijakan fiskal.

Lembaga keuangan mikro syariah Lembaga keuangan mikro syariah mengarah pada usaha-usaha pengumpulan dan penyaluran dana yang bersifat non profit seperti zakat, infaq dan sadaqah sedangkan baitut tamwil sebagai usaha pengumpulan dan penyaluran dana yang bersifat komersial. Usaha-usaha tersebut menjadi bagian yang tidak terpisahkan dari Lembaga keuangan mikro syariahsebagai lembaga pendukung kegiatan ekonomi masyarakat kecil yang berlandaskan syariah (Sudarsono, 2008; 303).

Menurut Ridwan $(2004,126)$ Lembaga keuangan mikro syariahmerupakan organisasi bisnis yang juga berperan sosial. Sebagai lembaga sosial Lembaga keuangan mikro syariahmemiliki fungsi seperti pengumpulan dana zakat, infaq, sadaqah dan wakaf dan sumber dana sosial lainnya. Sebagai lembaga bisnis Lembaga keuangan mikro syariahlebih mengembangkan usahanya pada sektor keuangan seperti simpan pinjam yang menghimpun dana dari anggota dan calon anggota (nasabah) serta menyalurkannya kepada sektor ekonomi yang halal dan menguntungkan.

\section{Fungsi dan Peran lembaga keuangan mikro syariah}

Menurut Ridwan (2004; 131), lembaga keuangan mikro syariahmemiliki fungsi sebagai berikut:

1. Mengidentifikasi, memobilasi, mengorganisasikan, mendorong dan mengembangkan potensi serta kemampuan potensi ekonomi anggotanya dan daerah kerjanya

2. Meningkatkan kualitas Sumber Daya Manusia anggota menjadi lebih profesional dan islami dalam menghadapi persaingan global.

3. Menggalang dan memobilisasi potensi masyarakat dalam rangka meningkatkan kesejahteraan anggota.

4. Menjadi perantara keuangan untuk dana-dana sosial seperti Zakat, Infaq, Sadaqah, Wakaf dan hibah

5. Menjadi perantara keuangan antara pemilik dana sebagai pemodal dan penyimpan dengan pengguna dana untuk mengembangkan usaha produktif.

Adapun peranan dari Lembaga keuangan mikro Syariah sebagai berikut (Soedarsono, 2008; 304):

1. Menjauhkan masyarakat dari praktek ekonomi ribawi dan aktif melakukan 
190 Irwan Suriadi, Hailuddin, Siti Sriningsih/Model Pengembangan Lembaga Keuangan Mikro...

sosialisasi kepada masyarakat berkaitan dengan arti pentingnya sistem ekonomi islam.

2. Melakukan pembinaan dan pendanaan bagi usaha kecil, seperti menjalankan fungsi sebagai pendamping, penyuluh, pengawas terhadap usaha-usaha nasabah.

3. Melepaskan ketergantungan masyarakat pada rentenir dengan memberikan pelayanan dengan mpenyediaan dana setiap saat dan membuat birokrasi yang sederhana.

4. Menjaga keadilan ekonomi masyarakat dengan distribusi yang merata.

\section{Prinsip-prinsip Utama dari lembaga keuangan mikro syariah}

Terdapat beberapa prinsip-prinsip utama yang dimiliki oleh Lembaga keuangan mikro syariah yaitu, (Ridwan, 2004; 130):

1. Keimanan dan ketaqwaan kepada Allah SWT dengan mengimplementasikan prinsip-prinsip syariah dan muamalat islam ke dalam kehidupan nyata.

2. Keterpaduan, adanya nilai-nilai spiritual dan moral yang menggerakkan etika bisnis yang adil dan berakhlak mulia.

3. Kekeluargaan, mengutamakan kepentingan bersama diatas kepentingan pribadi khususnya pengelola pada setiap tingkatan, pengurus dan anggotanya sehingga akan tumbuh rasa kekeluargaan

4. Kebersamaan, kesatuan pola pikir, sikap dan cita-cita antar semua elemen yang ada pada Lembaga keuangan mikro syariahseperti pengelola dan pengurus harus memiliki kesatuan visi untuk memperbaiki kondisi ekonomi dan sosial.

5. Kemandirian, mandiri diatas semua golongan politik dan tidak tergantung dengan dana-dana pinjaman dan bantuan tetapi proaktif dalam menggalang dana masyarakat sebanyak-banyaknya.

6. Profesionalisme, semangat kerja yang tinggi yang dilandasi dengan dasar keimanan yang berorientasi pada kehidupan dunia dan akhirat.

7. Istiqomah, adanya konsistensi, keberlanjutan tanpa henti dan putus asa dalam mencapai tujuan yang digariskan syariat.

\section{Prinsip-prinsip Operasional lembaga}

\section{keuangan mikro Syariah}

Dalam menjalankan usahanya Lembaga keuangan mikro syariahmemiliki prinsip operasional yang dibagi menjadi tiga bagian;

1. Prinsip bagi hasil, dimana terdapat pembagian hasil dari pemberi 
pinjaman dengan Lembaga keuangan mikro syariahyang terdiri dari;

a. Prinsip Al-Mudharabah (Bagi hasil). Prinsip al-mudharabah ini merupakan akad kerjasama usaha antara dua pihak, dimana pihak pertama (sahibul maal) menyediakan seluruh modal sedangkan pihak lainnya menjadi pengelola dengan keuntungan dibagi berdasarkan bagi hasil di dalam kontrak. Pada prinsip almudharabah ini jika terjadi kerugian, maka kerugian ditanggung oleh pemilik modal selama kerugian ini bukan akibat kelalaian pengelola.

b. Prinsip Al-Musyarakah (Penyertaan modal/Partnership). Prinsip dari almusyarakah ini merupakan akad kerjasama antara dua pihak atau lebih untuk suatu usaha tertentu di mana masing-masing pihak memberikan kontribusi dana dengan kesepakatan bahwa keuntungan dan resiko ditanggung bersama sesuai kesepakatan antara kedua belah pihak.

2. Prinsip Jual Beli, dimana Lembaga keuangan mikro syariahmengangkat nasabah sebagai agen yang diberi kuasa untuk melakukan pembelian barang atas nama Lembaga keuangan mikro syariahdan kemudian bertindak sebagai penjual dengan menjual barang yang telah dibelinya dengan harga mark-updan keuntungan akan dibagi dengan penyedia dana (Soedarsono,2008,308). Adapun jenisjenis prinsip jula beli adalah sebagai berikut :

a. Prinsip Al-Murabahah (Jual beli). Prinsip Al-Murabahah ini merupakan jual beli barang pada harga asal dengan tambahan keuntungan yang telah disepakati antara kedua belah pihak (pihak bank dan nasabah), dimana penjual harus memberitahu harga produk yang ia beli dan menentukan besaran tingkat keuntungan sebagai tambahannya

b. Prinsip Bai as-Salam. Prinsip Bai asSalam ini merupakan pembelian barang yang diserahkan di kemudian hari dengan pembayaran dilakukan dimuka.

c. Prinsip Bai Al-Istishna'. Prinsip Bai Al-Istishna' merupakan kontrak penjualan antara pembeli dan pembuat barang, dimana pembuat barang menerima pesanan dari pembeli, pembuat barang berusaha melalui orang lain untuk 
membuat atau membeli barang menurut sfesifikasi yang telah disepakati dan menjualnya pada pembeli akhir dengan kesepakatan harga dan sistem pembayaran.

3. Prinsip Non-Profit (pembiayaan kebajikan), pembiayaan ini bersifat sosial dan non komersial, dimana nasabah cukup mengembalikan pokok pinjamannya saja. Prinsip ini disebut dengan Al-Qardhul Hasan.

\section{Prosedur Pendirian lembaga keuangan} mikro Syariah (Baitul Maal Wattamwil/Lembaga Keuangan Mikro Syariah)

1. Modal pendirian Baitul Maal

Wattamwil (Lembaga Keuangan Mikro Syariah). Modal awal pendirian Lembaga keuangan mikro syariahadalah sebesar Rp 5.000.000, Rp.30.000.000, Rp 20.000.000 atau lebih. Modal awal pendirian Lembaga keuangan mikro syariahini bisa berasal dari mana saja seperti, personal, masyarakat, yayasan, kas masjid atau BAZIZ setempat. Anggota pendiri Lembaga keuangan mikro syariahharus terdiri dari 20-44 orang.

2. Badan hukum Baitul Maal Wattamwil (Lembaga Keuangan Mikro Syariah)

a. Kelompok swadaya masyarakat (KSM) dengan mendapat surat keterangan operasional dari
PINBUK (Pusat Inkubasi Bisnis Usaha Kecil)

b. Koperasi serba usaha/koperasi syariah

c. Koperasi simpan pinjam syariah

3. Tahapan pendirian Baitul Maal Wattamwil (Lembaga Keuangan Mikro Syariah)

a. Pemrakarsa membentuk panitia penyiapan pendirian Baitul Maal Wattamwil (P3B) di lokasi tertentu seperti masjid, pesantren, keluran, kecamatan, desa miskin

b. P3B mencari modal awal minimal sebesar Rp 5.000.000 untuk segera memulai langkah operasional, bisa dari perorangan, lembaga, yayasan, BAZIZ,Pemda dll.

c. Jika calon pemodal telah ada maka dipilih pengurus (3-5 orang) yang akan mewakili pendiri dalam operasional Baitul Maal Wattamwil (Lembaga Keuangan Mikro Syariah)

d. Melatih tiga calon pengelola dengan menghubungi Pusdiklat PINBUK Provinsi kab/Kota

e. Melaksanakan persiapanpersiapan sarana perkatoran dan formulir yang diperlukan

f. Menjalankan bisnis operasi Lembaga Keuangan Mikro Syariah dengan profesional dan sehat. 


\section{Kemiskinan}

Kemiskinan memiliki kaitan erat dengan pemerataan pendapatan, kemiskinan muncul akibat ketidakmampuan suatu daerah tertangani dengan baik sehingga menjadi terisolasi dengan adanya daerah yang harus menampung tenaga kerja yang melimpah sedangkan produktivitasnya rendah sehingga terjadi ketidakseimbangan produksi akibatnya daerah tersebut tidak dapat menikmati pembangunan.

\section{Konsep Kemiskinan}

Kemiskinan diartikan sebagai ketidakmampuan untuk memenuhi standar hidup minimum, kemiskinan biasanya diukur dengan tingkat pendapatan.

Kemiskinan dibagi menjadi dua bagian;

a. kemiskinan absolut, diartikan sebagai jumlah penduduk yg hidup dibawah garis kemiskinan yg tidak dapat memenuhi kebutuhan dasarnya seperti pangan, sandang, perumahan, kesehatan, pendidikan dan kebutuhan hidup layak lainnya.

b. kemiskinan relatif, diartikan sebagai keadaan perbandingan antar kelompok masyarakat dengan pendapatan yang sudah berada diatas garis kemiskinan. Sedangkan menurut Usman (1998) dalam Ridwan $(2004,5)$ menyebutkan konsep kemiskinan lebih dekat kepada kemiskinan subjektif, di mana kemiskinan didasarkan kepada perasaan kelompok atau orang yang miskin itu sendiri artinya kelompok yang menurut ukuran kita miskin namun menurut perasaan tidak miskin atau kelompok yang menurut standar hidup layak tergolong tidak layak tetapi perasaannya mengatakan layak dan begitupun sebaliknya.

\section{Pandangan islam tentang kemiskinan}

Islam selalu mengajarkan umatnya untuk selalu bekerja keras dalam segala usaha atuu aktivitas di dunia ini agar tidak terjerumus kepada jurang kemiskinan karena islam melarang umatnya menjadi orang miskin, di mana kemiskinan akan mendekati kepada kekufuran. Kemiskinan akan membawa seseorang untuk cenderung berbuat yang diharamkan.

Islam memberikan aturan cara mencari harta serta menganjurkan kepada pemiliknya untuk berusaha membantu sesama, sehingga islam menolak pahampaham ekstrim yang berkaitan dengan kemiskinan, paham-paham tersebut antara lain (Ridwan (2004,11-16).

1. Islam menolak paham yang mensucikan kemiskinan. Penolakan islam tidak saja pada pandangan yang mensucikan kemiskinan tetapi juga termasuk paham zuhud yang telah 
terpengaruh dengan budaya dari luar islam seperti pikiran manuisme persi, sufiisme hindu, kerahiban nasrani yang tidak satupun ayat dalam Al-Quran atau hadis nabi yang mensucikan kemiskinan.

2. Islam menolak pandangan jabbariah (Totalitas). Islam menolak pandangan ini karena pandangan ini mengarah pada kepasrahan total. Menurut paham ini kemiskinan sudah menjadi takdir, tidak satupun orang yang dapat merubahnya. Pandangan ini juga menganggap manusia tidak perlu bersusah payah mengubah nasibnya karena nasib memang sudah ditentukan. Penolakan islam terhadap paham ini adalah setiap orang tidak pernah tahu nasibnya dikemudian hari, manusia boleh merencanakan kehidupan serta berusaha keras dan islam mengajak umatnya untuk merubah nasibnya dari kondisi yang kurang baik menjadi lebih baik.

3. Islam menolak paham yang menggantungkan pada kesalehan pribadi dan sedekah suka rela. Islam menganjurkan umatnya untuk saling tolong menolong, membantu sesama, menyantuni fakir miskin, memelihara anak yatim tetapi islam menolak dari segi motivasinya. Karena menolong menurut pandangan ini semata-mata karena kesadaran individu, tidak ada ukuran yang jelas dan ketegasan tanggung jawab orang yang ditolong. Islam menilai pandangan ini tiak membawa kemajuan karena orang miskin akan senantiasa tergantung dari belas kasihan orang kaya.

4. Islam menolak pandangan kapitalisme. Islam menolak pandangan yang mengatakan bahwa harta adalah milik hakiki empunya, di mana mereka bebas membelanjakannya, orang tidak berhak sama sekali terhadap harta orang lain. Pandangan ini sama dengan kisah Qorun yang menyebutkan seluruh hartanya adalah hasil kerja kerasnya sendiri tanpa adanya campur tangan tuhan.

Islam menolak pandangan ini karena pemilik mutlak dari harta benda adalah Allah SWT, manusia hanya diberikan amanah untuk menjaganya dan suatu saat nanti akan dimintai pertanggungjawaban terhadap harta yang telah digunakannya.

5. Islam menolak paham Marxisme. Menurut paham ini kemiskinan hanya akan dapat diatasi dengan jalan menghapuskan hak individu dan menjadikannya hak bersama. Pandangan ini bertentangan dengan 
islam, kerana islam menghargai hakhak individu dan sosial.

Kaitan antara lembaga keuangan mikro dengan Kemiskinan

Fungsi intermediasi di dalam perekonomian dijalankan oleh lembaga keuangan mikro, dimana uang (kredit/pembiayaan) menjadi darahnya perekonomian, terutama akses modal kepada masyarakat miskin sangat dibutuhkan untuk mengurangi kemiskinan. Pengentasan kemiskinan dilakukan dengan berbagai sarana dan program baik yang

\section{METODE PENELITIAN}

\section{Jenis Penelitian}

Pendekatan penelitian yang digunakan dalam penelitian ini adalah pendekatan kualitatif deskriptif. Metode penelitian yang digunakan adalah metode FGD (Fokus Group Discussion) dan wawancara mendalam (indepth interview) telaah data sekunder atau dokumen dan studi kepustakaan.

Penentuan lokasi penelitian dilakukan secara purposive sampling yaitu dengan melakukan penentuan lokasi penelitian dengan sengaja dimana 6 KecamatanKota Mataram dijadikan tempat penelitian.

\section{Informan penelitian}

Informan yang digunakan dalam penelitian ini dipilih berdasarkan kesesuaian dan bersifat langsung maupun yang bersifat tidak langsung seperti melalui pemberdayaan usaha produktif melalui pinjaman dalam bentuk kredit mikro.

Kaitan antara pengentasan kemiskinan dengan pemberdayaan kredit mikro merupakan pintu masuk bagi orang yang akan menjadi pengusaha pemula agar mereka mendapat kesempatan untuk mengembangkan ide dan kreatifitas usahanya sehingga diharapkan akan memberikan pendapatan bagi masyarakat sekitar.

kecukupan dengan penelitian ini. Kesesuaian diartikan bahwa informan dipilih berdasarkan keterkaitan dengan judul penelitian ini, sedangkan kecukupan diartikan sebagai informan yang mengambil data nantinya diharapkan akan memberikan gambaran fenomena yang berkaitan dengan judul penelitian ini. Informan yang digunakan dalam penelitian ini adalah:

1. Nasabah Baitul Lembaga keuangan mikro syariah Maal Wattamwil (Lembaga Keuangan Mikro Syariah)

2. PINBUK Kota Mataram

3. Otoritas Jasa Keuangan (OJK) cabang Kota Mataram 
4. Pemilik Baitul Maal Wattamwil di Kota Mataram

5. Dinas Koperasi dan UMKM Kota Mataram

\section{Instrumen Penelitian}

Agar penelitian ini berjalan dengan lancar maka peneliti membuat panduan atu pedoman FGD dan pedoman wawancara mendalam (indept interview) yang dilengkapi dengan beberapa item-item pertanyaan yang berhubungan dengan focus penelitian. Selain itu juga untuk digunakan alat perekam suara (handphone) dan kamera digital untuk mendokumentasikan penelitian dan membantu membuat detail laporan hasil penelitian.

\section{Validasi Data}

Validasi data dilakukan dengan menggunakan sumber dan metode triangulasi.

1. Metode Triangulasi sumber. Validasi data ini digunakan untuk melakukan check and balances data dari sumber informan penelitian yang berbeda, informan dalam penelitian ini terdiri dari Pemilik dan nasabah Lembaga keuangan mikro syariah

2. Metode triangulasi. Metode ini menggunakan Focus Group Discussion (FGD), indept interview, melakukan penelaahan data sekunder dan studi kepustakaan.

\section{Pengolahan Data, Analisis Data dan Penyajian Data}

Langkah-langkah yang dilakukan dalam mengolah dan menganalisis data antara lain:

1. Hasil FGD dan indept interview dibuat dalam bentuk matrik

2. Menelaah hasil pengumpulan data dan infromasi yang diperoleh dari hasil wawancara dan telaah pustaka dokumen.

3. Analisis data menggunakan analisis isi yang mengelompokkan data yang telah terkumpul menurut kategori yang sama.

4. Penyajian data dibedakan menjadi dua, data primer dari hasil FGD dan indept interview disajikan dalam bentuk teks, sedangkan data sekunder disajikan dalam bentuk tabulasi

\section{Analisis SWOT}

Teknik analisis yang digunakan adalah analisis SWOT (Strength, Weakness, Opportunity, Treath) untuk merumuskan strategi kebijakan pengembangan Lembaga keuangan mikro syariahdalam mengurangi kemiskinan.

Analisis SWOT yang digunakan dalam penelitian ini adalah untuk membandingkan antara faktor eksternal 
peluang (opportunities) dan ancaman

(threats) dengan faktor internal kekuatan

(strengths) dan kelemahan (weaknesses).

Gambar 1 Diagram Analisis SWOT

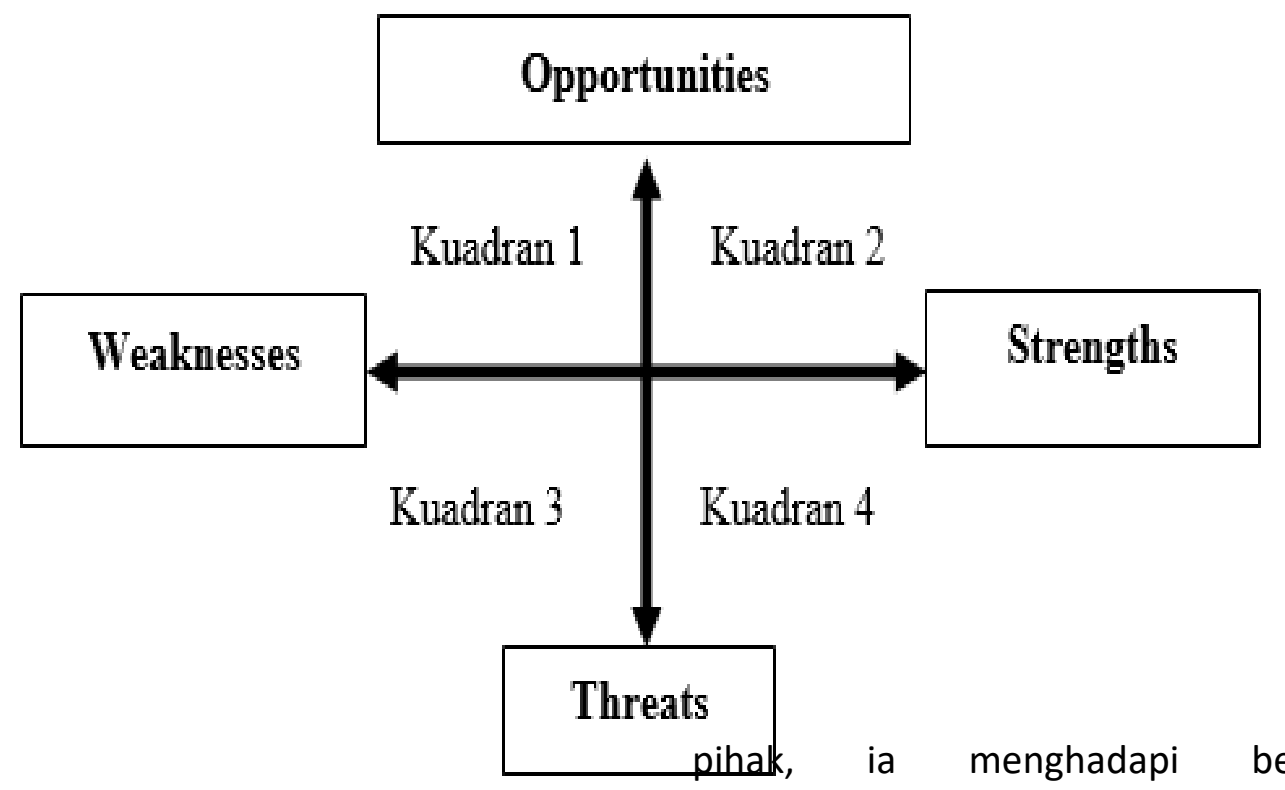

Kuadran 1 : Merupakan situasi yang sangat menguntungkan, organisasi memiliki peluang dan kekuatan sehingga dapat memanfaatkan peluang yang ada. Strategi yang harus diterapkan dalam kondisi ini adalah mendukung kebijakan pertumbuhan yang agresif.

Kuadran 2: Meskipun menghadapi berbagai ancaman, organisasi masih memiliki kekuatan dari segi internal. Strategi yang harus digunakan adalah menggunakan kekuatan untuk memanfaatkan peluang jangka panjang.

Kuadran 3 : Organisasi menghadapi peluang yang sangat besar, tetapi dilain kendala/kelemahan internal. Fokus strategi organisasi adalah meminimalkan masalah-masalah internal organisasi.

Kuadran 4: Ini merupakan situasi yang sangat tidak menguntungkan, organisasi menghadapi berbagai ancaman dan kelemahan.

Alat analisis yang dipakai untuk menyusun faktor-faktor strategis adalah matriks SWOT, matrik ini dapat menggambarkan secara jelas bagaimana peluang dan ancaman eksternal yang dihadapi yang dapat disesuaikan dengan kekuatan dan kelemahan yang dimiliki sehingga dapat menentukan alternatif strategi. 


\section{Gambar 2 Matrik SWOT}

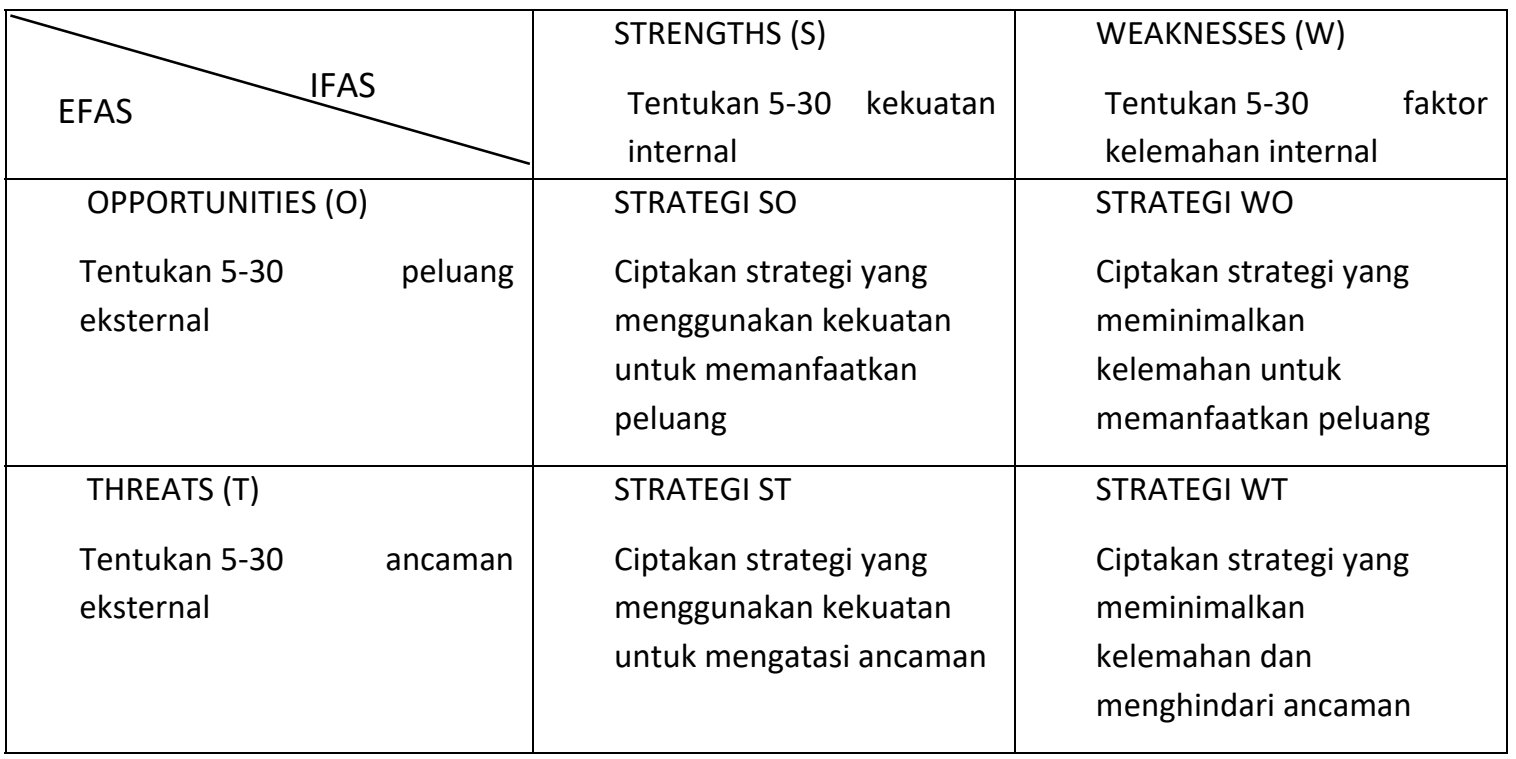

Sumber: (Rangkuti, 2002:31)

Penggunaan analisi SWOT dalam patokan dalam menyusun cetak biru penelitian ini adalah untuk merumuskan penanganan kemiskinan di Kota Mataram strategi kebijakan pemerintah daerah, Dinas Koperasi UMKM, OJK berdasakan

\section{ANALISIS DAN PEMBAHASAN}

\section{Analisis Penelitian}

Analisis SWOT Lingkungan Internal Lembaga Keuangan Mikro Syariah (BMT) diperoleh dilapangan adapat menjadi

Tabel 2 Tabel Analisis SWOT factor internal (kekuatan) Lembaga Keuangan Mikro Syariah

\begin{tabular}{|r|l|r|r|r|}
\hline No & Faktor internal & \multicolumn{1}{l|}{ Bobot } & \multicolumn{1}{l|}{ Rating } & \multicolumn{1}{l|}{ Skor } \\
\hline & KEKUATAN & & & \\
\hline 1 & Lokasi yg strategis & 0.08 & 3.50 & 0.28 \\
\hline 2 & Strategi jemput bola & 0.06 & 3.25 & 0.20 \\
\hline 3 & Pendidikan pengurus memadai & 0.06 & 2.50 & 0.15 \\
\hline & $\begin{array}{l}\text { Solidaritas yg tinggi antara pengurus dan } \\
\text { pengelola }\end{array}$ & 0.07 & 2.25 & 0.16 \\
\hline 5 & Memiliki kantor sendiri & 0.08 & 3.30 & 0.26 \\
\hline & Total Bobot kekuatan & $\mathbf{0 . 3 5}$ & $\mathbf{1 4 . 8}$ & $\mathbf{1 . 0 5}$ \\
\hline
\end{tabular}

Dari tabel 2 analisis SWOT penelitian dengan melihat factor internal Lembaga Keuangan Mikro Syariah (BMT) dengan menggunakan 5 Faktor seperti Faktor lokasi yang strategis, strategi jemput bola, pendidikan pengurus memadai, solidaritas yg tinggi antara pengurus dan pengelola serta memiliki kantor sendiri, dimana total keseluruhan nilai skor dari hasil pembobotan analisis SWOT adalah 1,05. 
Faktor strategi internal (kekuatan) yang memiliki nilai paling tinggi adalah lokasi yang strategis dengan skor tertinggi 0,28 , artinya Lembaga Keuangan Mikro Syariah (BMT) di Kota mataramharus memiliki lokasi yang strategis yaitu lokasi yang dekat dengan nasabah, dekat dengan pusat ekonomi, dekat dengan pasar agar Lembaga Keuangan Mikro Syariah (BMT) di Kota Mataram dapat berkembang untuk dapat memberikan bantuan permodalan usaha kepada masyarakat miskin atau masyarakat menengah kebawah sehingga kemiskinan di Kota Mataram dapat berkurang.

Faktor strategi internal (kekuatan) yang memiliki nilai paling tinggi kedua adalah BMT harus memiliki kantor sendiri dengan skor 0,26 artinya Lembaga Keuangan Mikro Syariah (BMT) di Kota mataramharus memiliki kantor sendiri agar dapat mempermudah pelayanan kepada masyarakat dan nasabah, selain itu juga Lembaga Keuangan Mikro Syariah (BMT) yang memiliki kantor sendiri akan lebih dipercaya oleh nasabah atau masyarakat karena dapat menunjukkan eksistensi BMT itu sendiri di mata nasabah atau masyarakat dan tentunya untuk lebih memudahkan operasional Lembaga Keuangan Mikro Syariah (BMT) dalam kegiatan pelayanan kepada nasabah atau masyarakat.

Untuk analisis SWOT factor internal (Kekuatan) Lembaga Keuangan Mikro Syariah (BMT) di Kota mataram terlihat bahwa skor seluruh bobot kekuatan sebesar 1,05 artinya strategi internal yang diterapkan masih lemah karena nilai skor bobot kurang dari 2,5.

Analisis SWOT Lingkungan internal Lembaga Keuangan Mikro Syariah (BMT)

Tabel 3 Tabel Analisis SWOT faktor internal (Kelemahan) Lembaga Keuangan MikroSyariah

\begin{tabular}{|r|l|r|r|r|}
\hline No & Faktor internal & \multicolumn{1}{l|}{ Bobot } & \multicolumn{1}{l|}{ Rating } & \multicolumn{1}{l|}{ Skor } \\
\hline & KELEMAHAN & & & \\
\hline 1 & Kurangnya pemanfaatan TI & 0.04 & 2.50 & 0.10 \\
\hline 2 & Tidak adanya ATM & 0.06 & 1.25 & 0.08 \\
\hline 3 & Kurangnya sosialisasi & 0.05 & 2.50 & 0.13 \\
\hline 4 & Kurangnya promosi & 0.04 & 2.55 & 0.10 \\
\hline 5 & Belum bisa melayani haji & 0.03 & 1.20 & 0.04 \\
\hline & Total Bobot kelemahan & $\mathbf{0 . 2 2}$ & $\mathbf{1 0}$ & $\mathbf{0 . 4 4}$ \\
\hline
\end{tabular}

Sumber: data diolah

Dari tabel 3 analisis SWOT penelitian dengan melihat factor internal Lembaga
Keuangan Mikro Syariah (BMT) dengan menggunakan 5 Faktor seperti Faktor 
Kurangnya pemanfaatan TI, Tidak adanya ATM, Kurangnya sosialisasi, Kurangnya promosi, Belum bisa melayani haji, dimana total keseluruhan nilai skor dari hasil pembobotan analisis SWOT adalah 0,44. Faktor strategi internal (Kelemahan) yang memiliki nilai paling tinggi adalah Kurangnya sosialisasi dengan skor tertinggi 0,13 artinya Lembaga Keuangan Mikro Syariah (BMT) di Kota Mataram harus melakukan sosialisasi dan promosi yang cukup gencar melalui pondok pesantren dan masjid-masjid agar masyarakat atau nasabah dapat menggunakan atau memanfaatkan produk Lembaga Keuangan Mikro Syariah (BMT) dengan baik sehingga tujuan BMT untuk memberikan kemaslahatan bagi masyarakat.

Faktor strategi internal (Kelemahan) yang memiliki nilai paling tinggi kedua adalah

kurangnya pemanfaatan IT (teknologi informasi) dengan skor 0,10 artinya Lembaga Keuangan Mikro Syariah (BMT) di Kota mataram belum menggunakan dan memanfaatkan teknologi dengan baik agar pelayanan yang di berikan kepada nasabah atau masyarakat dapat maksimal sehingga BMT di Kota mataram masih tertinggal dengan lembaga keuangan lainnya seperti perbankan syariah atau lembaga keuangan lainnya yang sejenis.

Untuk analisis SWOT factor internal (Kelemahan) Lembaga Keuangan Mikro Syariah (BMT) di Kota mataramterlihat bahwa skor seluruh bobot kelemahan sebesar 0,44 artinya strategi internal yang diterapkan masih lemah karena nilai skor bobot kurang dari 2,5.

Analisis SWOT Lingkungan eksternal Lembaga Keuangan Mikro Syariah (BMT)

\section{Tabel 4 Tabel Analisis SWOT factor Eksternal (Peluang) Lembaga Keuangan Mikro Syariah}

\begin{tabular}{|r|l|r|r|r|}
\hline No & Faktor eksternal & \multicolumn{1}{l|}{ Bobot } & \multicolumn{1}{l|}{ Rating } & \multicolumn{1}{l|}{ Skor } \\
\hline & PELUANG & & & \\
\hline 1 & Potensi pasar BMT yg luas & 0.06 & 3.00 & 0.18 \\
\hline 2 & Dekat dg pusat ekonomi & 0.05 & 3.65 & 0.18 \\
\hline 3 & BMT memberdayakan UMKM & 0.04 & 2.80 & 0.11 \\
\hline 4 & Sistem bagi hasil (syariah) BMT & 0.03 & 2.45 & 0.07 \\
\hline & BMT memberdayakan masyarakat & & & \\
5 & miskin & 0.07 & 3.15 & 0.22 \\
\hline & Total Bobot kekuatan & $\mathbf{0 . 2 5}$ & $\mathbf{1 5 . 0 5}$ & $\mathbf{0 . 7 7}$ \\
\hline
\end{tabular}

Sumber: data diolah

Dari tabel 4 analisis SWOT penelitian dengan melihat factor eksternal Lembaga Keuangan Mikro Syariah (BMT) dengan menggunakan 5 Faktor seperti Faktor Potensi pasar BMT yg luas, Dekat dg pusat ekonomi, BMT memberdayakan UMKM, 
Sistem bagi hasil (syariah) BMT, BMT memberdayakan masyarakat miskin dimana total keseluruhan nilai skor dari hasil pembobotan analisis SWOT adalah 0,77. Faktor strategi Eksternal (Peluang) yang memiliki nilai paling tinggi adalah BMT memberdayakan masyarakat miskin dengan skor tertinggi 0,22, artinya Baitul Maal Wattamwil (BMT) di Kota mataramdapat berkembang dengan baik karena memiliki peluang untuk pemberdayaan masyarakat di Kota matarammelalui bantuan permodalan dan pembiayaan kepada sector usaha mikro kecil sehingga akan dapat memberikan peluang juga untuk mengurangi kemiskinan di Kota Mataram.

Faktor strategi Eksternal (Peluang) yang memiliki nilai paling tinggi kedua adalah Potensi pasar BMT yg luas dengan skor 0,18 artinya Lembaga Keuangan Mikro
Syariah (BMT) di Kota mataram memiliki potensi pasar yang cukup besar untuk dilayani dan diberikan bantuan permodalan melalui pembiayaan karena jumlah penduduk Kota Mataram yang mayoritas penduduknya muslim atau beragama islam sehingga tinggal diberikan pemahaman dan sosialisasi kepada masyarakah atau nasabah agar dapat memahami seluk beluk atau segala hal yang berkaitan dengan Lembaga Keuangan Mikro Syariah (BMT).

Untuk analisis SWOT factor Eksternal (Peluang) Lembaga Keuangan Mikro Syariah (BMT) di Kota mataram terlihat bahwa skor seluruh bobot peluang sebesar 0,77 artinya strategi eksternal yang diterapkan masih lemah karena nilai skor bobot kurang dari 2,5.

Analisis SWOT Lingkungan eksternal Lembaga Keuangan Mikro Syariah (BMT)

Tabel 5 Tabel Analisis SWOT factor Eksternal (Ancaman) Lembaga Keuangan Mikro Syariah

\begin{tabular}{|r|l|r|r|r|}
\hline No & Faktor eksternal & \multicolumn{1}{l|}{ Bobot } & \multicolumn{1}{l|}{ Rating } & \multicolumn{1}{l|}{ Skor } \\
\hline & ANCAMAN & & & \\
\hline 1 & Kurangnya modal BMT & 0.03 & 2.70 & 0.08 \\
\hline 2 & Kualitas SDI masih kurang & 0.05 & 1.70 & 0.09 \\
\hline 3 & Adanya KUR & 0.04 & 2.30 & 0.09 \\
\hline 4 & Kurangnya penggunaan TI & 0.03 & 2.35 & 0.07 \\
\hline & Bank syariah yg menggarap pasar & & & \\
5 & mikro & 0.06 & 3.48 & 0.21 \\
\hline & Total Bobot kelemahan & $\mathbf{0 . 2 1}$ & $\mathbf{1 2 . 5 3}$ & $\mathbf{0 . 5 4}$ \\
\hline
\end{tabular}

Sumber: data diolah

Dari tabel 5 analisis SWOT penelitian dengan melihat factor eksternal Lembaga Keuangan Mikro Syariah (BMT) dengan menggunakan 5 Faktor seperti Faktor Kurangnya modal BMT, Kualitas SDI masih kurang, Adanya KUR, Kurangnya 
penggunaan $\mathrm{TI}$, Bank syariah yg menggarap pasar mikro dimana total keseluruhan nilai skor dari hasil pembobotan analisis SWOT adalah 0,54. Faktor strategi Eksternal (Ancaman) yang memiliki nilai paling tinggi adalah Bank syariah yg menggarap pasar mikro dengan skor tertinggi 0,21 artinya Baitul Maal Wattamwil (BMT) di Kota matarammemiliki pesaing yang cukup berat yaitu dari bank syariah yang mulai menggarap sector mikro atau nasabah mikro kecil yang selama ini menjadi pasar yang cukup potensial bagi BMT Kota mataram, belum lagi adanya pesaing dari bank konvesional yang selama ini menggarap sector mikro kecil seperti bank BRI konvesional yang telah lebih dahulu menggarap sector mikro dan cukup berpengalaman dalam bidang ini sehingga factor ini menjadi ancaman yang cukup serius bagi BMT di Kota Mataram.

Faktor strategi Eksternal (ancaman) yang memiliki nilai paling tinggi kedua adalah adanya KUR (Kredit usaha rakyat) artinya Lembaga Keuangan Mikro Syariah (BMT) di Kota mataram memiliki ancaman dari pesaing perbankan konvesional yang memberikan fasilitas KUR kepada nasabah mikro kecil sehingga pangsa pasar BMT di kota mataram semakin berkurang dan persaingan untuk mendapatkan nasabah atau anggota BMT semakin ketat.
Untuk analisis SWOT factor Eksternal (ancaman) Lembaga Keuangan Mikro Syariah (BMT) di Kota mataramterlihat bahwa skor seluruh bobot ancaman sebesar 0,54 artinya strategi eksternal yang diterapkan masih lemah karena nilai skor bobot kurang dari 2,5.

\section{Pembahasan}

Dari analisis SWOT diatas terlihat bahwa Faktor strategi internal (Kekuatan) yang memiliki nilai paling tinggi adalah Kurangnya sosialisasi dengan skor tertinggi 0,13 artinya Lembaga Keuangan Mikro Syariah (BMT) di Kota mataram harus melakukan sosialisasi dan promosi yang cukup gencar melalui pondok pesantren dan masjid-masjid agar masyarakat atau nasabah dapat menggunakan atau memanfaatkan produk BMT dengan baik sehingga tujuan BMT untuk memberikan kemaslahatan bagi masyarakat dapat tercapai. Faktor strategi internal (Kelemahan) yang memiliki nilai paling tinggi adalah Kurangnya sosialisasi dengan skor tertinggi 0,13 artinya Lembaga Keuangan Mikro Syariah (BMT) di Kota mataram harus melakukan sosialisasi dan promosi yang cukup gencar melalui pondok pesantren dan masjid-masjid agar masyarakat atau nasabah dapat menggunakan atau memanfaatkan produk BMT dengan baik sehingga tujuan BMT 
untuk memberikan kemaslahatan bagi masyarakat dapat tercapai. Faktor strategi Eksternal (Peluang) yang memiliki nilai paling tinggi adalah BMT memberdayakan masyarakat miskin dengan skor tertinggi 0,22, artinya Lembaga Keuangan Mikro Syariah (BMT) di Kota mataram dapat berkembang dengan baik karena memiliki peluang untuk pemberdayaan masyarakat di Kota mataram melalui bantuan permodalan dan pembiayaan kepada sector usaha mikro kecil sehingga akan dapat memberikan peluang juga untuk mengurangi kemiskinan di kota mataram. Faktor strategi Eksternal (Ancaman) yang memiliki nilai paling tinggi adalah Bank syariah yg menggarap pasar mikro dengan skor tertinggi 0,21 artinya Lembaga Keuangan Mikro Syariah (BMT) di Kota mataram memiliki pesaing yang cukup berat yaitu dari bank syariah yang mulai menggarap sector mikro atau nasabah mikro kecil yang selama ini menjadi pasar yang cukup potensial bagi BMT di kota mataram, belum lagi adanya pesaing dari bank konvesional yang selama ini menggarap sector mikro kecil seperti bank BRI konvesional yang telah lebih dahulu menggarap sector mikro dan cukup berpengalaman dalam bidang ini sehingga factor ini menjadi ancaman yang cukup serius bagi BMT di kota mataram. Dari hasil analisis SWOT diatas juga dapat dirumuskan strategi pengembangan Lembaga Keuangan Mikro Syariah (BMT) di Kota mataram sebagai berikut ;

1. Melakukan sosialisasi tentang konsep keuangan mikro syariah (BMT) ke masyarakat.

2. Pelatihan ke pada pegawai BMT berkaitan dgn pemasaran dan pelayanan nasabah

3. Menambah teknologi pendukung untuk operasional BMT

4. Membuat webside dan mempromosikan produk BMT

5. Membangun relationship dengan masyarakat sekitar

6. Turun ke pasar-pasar / jemput bola untuk mencari nasabah/anggota BMT

\section{KESIMPULAN DAN SARAN}

\section{Kesimpulan}

1. Faktor pendukung dapat dilihat dari kekuatan dan peluang yang dimiliki oleh Lembaga Keuangan Mikro Syariah (BMT) di Kota Mataram yaitu Lembaga Keuangan Mikro Syariah (BMT) di Kota mataramharus memiliki lokasi yang strategis yaitu lokasi yang dekat dengan nasabah, dekat dengan pusat ekonomi, dekat dengan pasar agar Lembaga Keuangan Mikro Syariah (BMT) di Kota Mataram dapat berkembang untuk dapat memberikan bantuan 
permodalan usaha kepada masyarakat miskin atau masyarakat menengah kebawah sehingga kemiskinan di Kota Mataram dapat berkurang dan BMT memberdayakan masyarakat miskin artinya Lembaga Keuangan Mikro Syariah (BMT) di Kota mataramdapat berkembang dengan baik karena memiliki peluang untuk pemberdayaan masyarakat di Kota mataram melalui bantuan permodalan dan pembiayaan kepada sector usaha mikro kecil sehingga akan dapat memberikan peluang juga untuk mengurangi kemiskinan di Kota Mataram.

2. Faktor Penghambat dapat dilihat dari kelemahan dan ancaman yang dimiliki oleh BMT di Kota Mataram yaitu Kurangnya sosialisasi artinya Lembaga Keuangan Mikro Syariah (BMT) di Kota mataramharus melakukan sosialisasi dan promosi yang cukup gencar melalui pondok pesantren dan masjid-masjid agar masyarakat atau nasabah dapat menggunakan atau memanfaatkan produk BMT dengan baik sehingga tujuan BMT untuk memberikan kemaslahatan bagi masyarakat dapat tercapai dan Bank syariah yg menggarap pasar mikro artinya Lembaga Keuangan Mikro Syariah (BMT) di Kota mataram memiliki pesaing yang cukup berat yaitu dari bank syariah yang mulai menggarap sector mikro atau nasabah mikro kecil yang selama ini menjadi pasar yang cukup potensial bagi Lembaga Keuangan Mikro Syariah (BMT) di kota mataram.

3. Strategi kebijakan Lembaga Keuangan Mikro Syariah (BMT) yaitu dalam menghadapi ancaman BMT di Kota Mataram harus terus menerus mengembangkan diri secara kreatif,inovatif,dan selalu memiliki perbaikan dalam pelayanan kepada nasabah BMT, pemerintah juga harus memberikan fasilitas kepada BMT terutama bantuan permodalan dan fasilitas-fasilitas agar BMT dapat berkembang dengan baik.

\section{Saran}

1. Manajemen Lembaga Keuangan Mikro Syariah (BMT) di Kota Mataram harus meningkatkan kualitas pelayanan kepada nasabah dengan menambah fasilitas seperti pemanfaatan teknologi informasi (TI).

2. Sosialisasi yang berkaitan dengan pemahaman produk dan sistem Lembaga Keuangan Mikro Syariah (BMT) harus ditingkatkan kepada masyarakat melalui ceramah dan khutbah di masjid maupun melalui 
pondok pesantren agar nasabah BMT semakin berkembang.

3. Karyawan Lembaga Keuangan Mikro Syariah (BMT) harus meningkatkan pemahaman berkaitan dengan sistem syariah agar nasabah paham dengan sistem dan operasional Lembaga Keuangan Mikro Syariah (BMT) melalui pelatihan dan training tentang Manajemen lembaga keuangan mikro syariah khususnya Lembaga Keuangan Mikro Syariah (BMT).

\section{DAFTAR PUSTAKA}

Antonio, Syafi'i. 2001. Bank Syariah “Dari teori ke praktek". Gema Insani Press.Jakarta Abu Umar Faruq Ahmad and A. B. Rafique Ahmad. Islamic Microfinance:

A Case Study of Australia. Journal of Islamic Econ 60 omics, Banking and Finance Asyraf Wajdi Dusuki (2007). Banking for the Poor: The Role of Islamic Banking in Microfinance Initiatives. Proceedings of the 2nd Islamic Conference 2007 (iECONS2007) organized by Faculty of Economics and Muamalat, Islamic Science University of Malaysia.

Kuncoro, Mudrajad. 2003. Metode Riset Untuk Ekonomi dan Bisnis. Erlangga.Jakarta Muhammad. 2002. Manajemen bank syariah. UPP AMP YKPN. Jogjakarta.

Sudarsono, Heri. 2008. Bank dan Lembaga Keuangan Syariah"Deskripsi dan Ilustrasi”. Edisi 3. Ekonisia. Jogjakarta.

Syeda Shehrbano Kazim dan Syed Eisar Haider. 2012. Islamic microfinance Models And their viability In pakistan. Pakistan Microfinance Network No. 15 Juni 2012

Nurkholis (2009). The contribution of islamic microfinance institution in Increasing social welfare in indonesia (a case study of lembaga keuangan mikro syariah's role at pakem market micro Traders yogyakarta). Islamic Economic Department, Faculty of Islamic Studies, Islamic University of Indonesia,Yogyakarta, Indonesia.

Ridwan, Muhammad. 2004. Manajemen Baitul Maal Wattamwil. UII Press. Jakarta

Rangkuti, Freddy. 2002. Analisis SWOT Teknik Membedah Kasus Bisnis, PT. Gramedia Pustaka Utama: Jakarta.

Wiloejo Wirjo Wiyono (2005). Pemberdayaan lembaga keuangan mikro sebagai salah satu pilar sistem keuangan nasional : upaya konkrit memutus mata rantai kemiskinan. Jurnal kajian ekonomi dan keuangan edisi khusus Desember 2005. Jakarta 